\title{
The first international standard for antibodies to double stranded DNA*
}

\author{
T E W FELTKAMP, ${ }^{1} \mathrm{~T}$ B L KIRKWOOD, ${ }^{2} \mathrm{R} \mathrm{N}$ MAINI, ${ }^{3}$ AND L A AARDEN ${ }^{1}$
}

From the ${ }^{1}$ Central Laboratory of the Netherlands Red Cross Blood Transfusion Service, Amsterdam, The $e^{\infty}$ Netherlands; the ${ }^{2}$ National Institute for Medical Research, Mill Hill, London; and the ${ }^{3}$ Kennedy Institute of $\overrightarrow{0}$ Rheumatology, Hammersmith, London

SUMMARY This paper announces the availability of the first international standard fors anti-double-stranded DNA (anti-dsDNA). The material, coded Wo/80, was obtained after ${ }_{0}$ recalcification of plasma taken from a patient with systemic lupus erythematosus. Vials were filled with $500 \mu \mathrm{l}$ serum and freeze dried. The serum contains no other autoantibodies in ${ }^{\circ}$ measurable quantities. The vials should be stored at $-20^{\circ} \mathrm{C}$. The standard should be used for establishing national, regional, or local standards. In eight laboratories satisfactory results with $\vec{f}^{\circ}$ the immunofluorescence technique on Crithidia luciliae were obtained; the titres varied betweenf

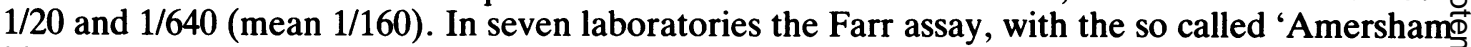
kit', was performed. At a dilution of 1:40 a mean binding percentage of about $50 \%$ was observed. After reconstitution with $500 \mu \mathrm{l}$ of distilled water, the vial contains $100 \mathrm{IU} / 500 \mu \mathrm{l}$ or $200 \mathrm{IU} / \mathrm{ml}$. The standard can be obtained from the custodian of WHO: Central Laboratory of theo Netherlands Red Cross Blood Transfusion Service, PO Box 91901006 AD Amsterdam, The $e^{\infty}$ Netherlands.

Key words: anti-DNA, standardisation, WHO, Farr assay, Crithidia luciliae, IUIS.

Thirty years ago antibodies to DNA were first reported in sera from patients with systemic lupus erythematosus. ${ }^{1-4}$ Numerous methods have been developed for the detection of these antibodies, ${ }^{5-8}$ and it has been generally agreed that for measurement of the amount of anti-DNA, serum dilutions should be tested. The results could then be expressed, depending on the method, either in arbitrary units per millilitre or as a titre. ${ }^{89}$

During the first Bertine Koperberg Conference the need for an international standard anti-dsDNA antiserum was expressed. ${ }^{10}$ Such a standard serum should allow the development of national standards, which finally should lead to the use of local laboratory reference sera, enabling the expression of quantitative results in international units (IU).

The standardisation committee of the International

Accepted for publication 3 February 1988.

Correspondence to Professor T E W Feltkamp, c/o Publication Secretariat, Central Laboratory of the Netherlands Red Cross Blood Transfusion Service, PO Box 9406, 1006 AK Amsterdam, The Netherlands.

*This article is written on behalf of the International Union of Immunological Societies standardisation committec on anti-dsDNA.
Union of Immunological Societies nominated for $\overrightarrow{\overrightarrow{0}}$ this purpose a subcommittee on anti-dsDNA. The 3 chairman of this committee, T E W Feltkamp, received support from many workers all over the world (see 'Acknowledgments'). The nucleus of the committee, i.e., the authors of the present paper and E J Holborow and G D Johnson, agreed that 3 the committee's task was to develop a referencer standard serum which was available in a large 3 quantity and contained anti-dsDNA activity, was stable when stored in freeze dried ampoules, and was suitable for use in at least the Farr assay and the immunofluorescence technique. These two techniques had performed consistently well in a com- $N$ parative study organised by the Arthritis and $N$ Rheumatism Council of Great Britain ${ }^{6}$ and relied upon the use of dsDNA which was relatively free ${ }^{\omega}$ from contamination by single stranded DNA and nucleoprotein. $^{7}$

\section{Materials and methods}

PATIENT Wo

Patient Wo was a man, born in 1924, who developed 
pleuritis in 1954. Since 1954 he had also had arthralgia, arthritis, Raynaud's phenomenon, and skin rashes. In 1976 an exacerbation of his disease comprised serious skin involvement (exfoliative dermatitis, mouth ulcerations), thrombocytopenia $\left(50 \times 10^{9} / 1\right)$, and leucopenia $\left(1 \cdot 3 \times 10^{9} / 1\right)$. Treatment was started with large doses of prednisone $(80 \mathrm{mg}$ daily). Anti-DNA was not found in the serum until July 1978. Since then the level of anti-DNA increased until an exacerbation in January 1979, during which the level dropped considerably in a few weeks. He then developed proteinuria with hyaline cylinders. In 1980 treatment with plasmapheresis was tried, but was unsuccessful. The patient developed serious mental depression and committed suicide.

PREPARATION OF STANDARD SERUM The anti-dsDNA standard serum was prepared by recalcification of plasma ( 2 litres) of patient Wo with $\mathrm{CaCl}_{2}$ to a final concentration of $15 \mathrm{mmol} /$. Clotting was allowed to take place for four hours at $37^{\circ} \mathrm{C}$, then for 16 hours at room temperature, after which the clot was removed by centrifugation. Neither hepatitis B surface antigens nor antihuman immunodeficiency virus were detected. The serum was divided among 1800 vials and freeze dried. The vials were back filled with dry, sterile, oxygen free nitrogen and stoppered in situ in the freeze drier. Labelling and oversealing of the vials was carried out by machine. Vial to vial analysis on 12 randomly selected vials gave a between assay coefficient of variation of $0 \cdot 8 \%$. Vials of a patient with systemic lypus erythematosus, patient ' $\mathrm{B}$ ', and a normal control, 'A', were also freeze dried. These were used for the collaborative study.

\section{OTHER A UTOANTIBODIES}

The serum Wo/80 was tested for several autoantibodies. Rheumatoid factors (latex test and WaalerRose test) and antiperinuclear factors could not be detected. Antibodies to extractable nuclear antigens were not detectable by the counterimmunoelectrophoresis method. Apart from antinuclear antibodies, no antibodies were demonstrated by the indirect immunofluorescence technique against thyroid, gastric parietal cells, mitochondria, liver cells, skin, cornea, islets of Langerhans, tubular membranes, salivary duct cells, cardiac muscle, smooth muscle, skeletal muscle, adrenocortex, and gluten. A radioimmunoprecipitation method demonstrated no antibodies to acetylcholine receptors.

\section{Results}

STA B I LITY TESTING

Thirty vials of $\mathrm{Wo} / 80$ were stored at $-70^{\circ} \mathrm{C}$ until the onset of a fixed period during which the vials were stored at a specified temperature. All periods ended on the same date, on which all vials were opened and reconstituted. The contents were tested by the Farr assay (Table 1) and the immunofluorescence technique (Table 2).

Table 1 Accelerated degradation tests on freeze dried vials of Wo/80*

\begin{tabular}{|c|c|c|c|c|c|}
\hline \multirow{2}{*}{$\begin{array}{l}\text { Temperature } \\
\left({ }^{\circ} \mathrm{C}\right)\end{array}$} & \multicolumn{5}{|c|}{ Storage time } \\
\hline & 2 Weeks & 1 Month & 3 Months & 6 Months & 1 Year \\
\hline-70 & & & & & 178 \\
\hline-20 & & & & 185 & 172 \\
\hline 4 & & & 172 & 167 & 180 \\
\hline Room temperature & & 178 & 185 & 156 & 156 \\
\hline 37 & 180 & 183 & 149 & 136 & 125 \\
\hline
\end{tabular}

${ }^{*}$ The results are expressed in local units of anti-DNA/ml (Farr assay) as described by Aarden and Smecnk. ${ }^{7}$

Table 2 Accelerated degradation tests on freeze dried vials of Wo/80 using the indirect immunofluorescence technique on Crithidia luciliae

\begin{tabular}{llllll}
\hline $\begin{array}{l}\text { Temperature } \\
\text { ( C) }\end{array}$ & \multicolumn{2}{l}{ Storage time } & & & \\
\cline { 2 - 6 } & 2 Weeks & I Month & 3 Months & 6 Months & 1 Year \\
\hline-70 & & & $1 / 40$ & $1 / 80$ \\
-20 & & $1 / 80$ & $1 / 40$ & $1 / 40$ & $1 / 80$ \\
4 & $1 / 80$ & $1 / 80$ & $1 / 40$ & $1 / 80$ & $1 / 80$ \\
Room temperature & & & $1 / 40$ & $1 / 80$ \\
37 & & & & \\
\hline
\end{tabular}


The relative potency estimates were used to fit an Arrhenius equation relating degradation rate to absolute temperature by the maximum likelihood method. ${ }^{11}$ Data from the immunofluorescence technique assay (Table 2) were too variable for any conclusion to be drawn as there was no clear evidence of measurable degradation relative to the background error of the assay results. The data from the Farr assay (Table 1), however, provided a good fit to the Arrhenius model $\left(\chi^{2}=4.92 ; \mathrm{df}=12\right.$; $p>0.5)$. When the Farr assay data were analysed it was assumed that the geometric coefficient of variation of individual potency ratios was around $8.8 \%$ (equivalent to a statistical weight of 750 ) because this was typical of the values obtained in the collaborative study; the exact figure for precision was not known as this had not been determined.

When the fitted Arrhenius equation was used to predict long term stability of $\mathrm{Wo} / 80$ at $-20^{\circ} \mathrm{C}$ the estimated degradation rate was $0.045 \%$ a month or $0.54 \%$ a year. ${ }^{12}$ The half life $\left(t_{1 / 2}\right)$ at $-20^{\circ} \mathrm{C}$ is 128 years. An approximate upper $95 \%$ confidence limit for this rate is $3.5 \%$ per year. ${ }^{13}$ These figures indicate an acceptable level of long term stability for $\mathrm{Wo} / 80$ when stored at $-20^{\circ} \mathrm{C}$ or below. For periods of shipment the data indicate a predicted loss of $3.3 \%$ activity a month at $37^{\circ} \mathrm{C}$ and $1.1 \%$ activity a month at $20^{\circ} \mathrm{C}$. These losses also appear to be acceptable.

Tests on the stability of the reconstituted content of $\mathrm{Wo} / 80$ when stored at $-20^{\circ} \mathrm{C}$ also showed reasonable stability under these conditions (Table 3).

\section{COLLABORATIVE STUDY}

From the members of the subcommittee on standardisation of anti-dsDNA eight (see 'Acknowledgments') were selected for their experience in anti-dsDNA testing and willingness to cooperate in a study to see whether the serum Wo/80 could serve as a standard. The laboratories of these members

Table 3 Stability of the reconstituted content of vials $\mathrm{Wo} / 80$ if stored at $-20^{\circ} \mathrm{C}^{*}$

\begin{tabular}{|c|c|c|c|c|c|c|c|}
\hline \multirow[t]{2}{*}{ Vial } & \multicolumn{7}{|c|}{ Storage time after reconstitution (weeks) } \\
\hline & 0 & 8 & 10 & 11 & 21 & 23 & 24 \\
\hline $\mathbf{A}$ & 296 & & & 270 & & & 233 \\
\hline B & 250 & & 222 & & & 238 & \\
\hline C & 294 & 250 & & & 250 & & \\
\hline D & 250 & & & 256 & & & \\
\hline
\end{tabular}

were situated in Amsterdam, Bethesda, Giessen, Lą Jolla, London (two), Stockholm, and Toulouse. के

From another centre outside these laboratorie vials with 10 freeze dried serum samples $\mathrm{Wo} / 80, \mathrm{~A} \stackrel{\text { ? }}{+}$ and B were shipped together with slides witle Crithidia luciliae prepared by the Central Labora음 tory of the Netherlands Red Cross Blood Transfu今 sion Service, (CLB), Amsterdam, ampoules of the WHO standard of fluorescein isothiocyanate (FITC conjugated anti-immunoglobulin (480010), and kits for the Farr assay as produced and provided by Amersham International plc. ${ }^{14}$

The eight laboratories were asked to test the ampoules A, B, and $\mathrm{Wo} / 80$ on four separate date with the immunofluorescence technique and the Farr assay according to fixed protocols. The test had to be performed within six weeks.

The fixed protocols were as follows: Reconstitute the freeze dried standard $\mathrm{Wo} / 80$ and the serum samples A and B with $500 \mu$ l distilled water by gently adding the water to the inside of the glass vial Replace the stoppers and leave the vials at roon

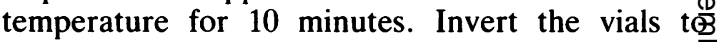
remove any remaining particles from the cap an\$ leave for a further five minutes. Mix gently to obtain. a homogeneous solution. The solution was equidaco lent to neat serum. Unless otherwise specified, $\rightarrow 1^{\circ}$ further dilutions were made with phosphate buffo fered saline (PBS; 0.01 $\mathrm{M} \mathrm{Na}_{2} \mathrm{HPO}_{4}-\mathrm{NaH}_{2} \mathrm{PO}_{4}, 0 \cdot 1$ $\mathrm{M} \mathrm{NaCl} ; \mathrm{pH} \mathrm{7.4).}$

\section{FARR ASSAY AS PRESENTED IN THE 'A M ERSHAM K I T'}

Prepare 1:10 dilutions of $W o / 80$, serum $A$, an $\$$ serum B by mixing $50 \mu \mathrm{l}$ of the sample with $450 \mu \mathrm{l}$ of borate buffered saline (buffer $A$ in the kit). Make three further doubling dilutions of the samples using serum buffer (buffer $B$ in the kit). Pipette $50 \mu \mathbb{P}$ aliquots of all the dilutions into duplicate tubes? cover, and incubate at $56^{\circ} \mathrm{C}$ for 30 minutes. Allow the tubes to cool and add $50 \mu$ l of the ${ }^{125} \mathrm{I}$ labelle DNA provided to all tubes and mix gently. Incubate at $37^{\circ} \mathrm{C}$ for 60 minutes and then for a minimum of 18 hours at $4^{\circ} \mathrm{C}$. Add to each tube $100 \mu \mathrm{l}$ of the cold saturated ammonium sulphate solution provide and mix immediately. Centrifuge the tubes at $1500 \mathrm{~g}$ for 15 minutes. Aspirate the supernatant and count the precipitate with a gammacounter. Draw dilutiop curves for all the samples.

IMMUNOFLUORESCENCE TECHNIQUE ON CRITHIDIA LUCILIAE

Prepare 1:10 dilutions of $W o / 80$, serum $A$, and serum $B$ and make seven further doubling dilutions in PBS. Pipette $30 \mu$ l aliquots of all serum dilution onto the spots of $C$ luciliae and incubate for 38 
minutes at room temperature in a damp atmosphere. Rinse each slide quickly under the tap and wash in an excess of PBS for 30 minutes at room temperature, changing the PBS every 10 minutes. Add to each slide an excess of a 1:40 dilution in PBS of the WHO standard FITC conjugated sheep antihuman immunoglobulin preparation. Prevent any drying out of the slides during this procedure. Incubate for 30 minutes at room temperature in a humid atmosphere. Wash as previously. Mount the slides in $65 \%(\mathrm{w} / \mathrm{v})$ sucrose in PBS $\mathrm{pH} 8.0$. When a KP 560 barrier filter (Leitz) is available reading is made much easier by introduction of $0.5 \mu \mathrm{g} / \mathrm{ml}$ propidium iodide to the $65 \%(\mathrm{w} / \mathrm{v})$ sucrose used for mounting. This stains the kinetoplast and nucleus red and facilitates localisation of the kinetoplast.
Read the slides with the local immunofluorescence microscope (magnification $500 \times$ ). Reading can be done with a 50/1.00 water immersion objective.

Tables 4 and 5 give the raw data. The eight laboratories are coded by numbers 1 to 8 . The laboratories cooperated satisfactorily. Only laboratory 8 failed to perform the Farr assay. Laboratory 2 missed some results because of broken tubes. Laboratory 6 did not perform the Farr assay on four days but in duplicate on three days. The results of the first day testing of the Farr assay in laboratory 6 allowed no proper comparison with those of the other laboratories. The immunofluorescence technique gave no problems except for laboratory 6 , who obtained negative results with serum $B$ on the third day.

Table 4 Farr assay performed by eight laboratories using the 'Amersham kit' on three sera*

\begin{tabular}{|c|c|c|c|c|c|c|c|c|c|c|c|c|c|}
\hline \multirow[t]{2}{*}{ Laboratory } & \multirow{2}{*}{$\begin{array}{l}\text { Test } \\
\text { No }\end{array}$} & \multicolumn{4}{|c|}{ Wo/80, dilution } & \multicolumn{4}{|c|}{$A$, dilution } & \multicolumn{4}{|c|}{$B$, dilution } \\
\hline & & $1 / 10$ & $1 / 20$ & $1 / 40$ & $1 / 80$ & $1 / 10$ & $1 / 20$ & $1 / 40$ & $1 / 80$ & $1 / 10$ & $1 / 20$ & $1 / 40$ & $1 / 80$ \\
\hline \multirow[t]{4}{*}{1} & 1 & 85 & 72 & 55 & 36 & 13 & 13 & 13 & 13 & 61 & 41 & 28 & 20 \\
\hline & 2 & 87 & 74 & 51 & 37 & 14 & 15 & 15 & 16 & 68 & 40 & 29 & 22 \\
\hline & 3 & 82 & 70 & 51 & 35 & 13 & 14 & 14 & 15 & 69 & 46 & 32 & 23 \\
\hline & 4 & 81 & 66 & 48 & 34 & 15 & 15 & 15 & 14 & 60 & 41 & 30 & 24 \\
\hline \multirow[t]{4}{*}{2} & 1 & 80 & 62 & 47 & 34 & 10 & 11 & 9 & 9 & 55 & 38 & 24 & 16 \\
\hline & 2 & 77 & 49 & 46 & 31 & 18 & 14 & 14 & 14 & 41 & 29 & 29 & 24 \\
\hline & 3 & 98 & 51 & 43 & 32 & 14 & - & - & - & 49 & 31 & 17 & 17 \\
\hline & 4 & 62 & 46 & 36 & 22 & 11 & 11 & 10 & 9 & 38 & 24 & 21 & 11 \\
\hline \multirow[t]{3}{*}{3} & 1 & 85 & 69 & 51 & 38 & 18 & 16 & 17 & 16 & 52 & 37 & 24 & 20 \\
\hline & 2 & 89 & 76 & 54 & 37 & 17 & 14 & 13 & 12 & 55 & 37 & 26 & 19 \\
\hline & 4 & 84 & 70 & 49 & 32 & 15 & 13 & 13 & 14 & 56 & 38 & 24 & 19 \\
\hline \multirow[t]{4}{*}{4} & 1 & 79 & 65 & 54 & 37 & 16 & 16 & 18 & 16 & 58 & 41 & 33 & 23 \\
\hline & 2 & 85 & 71 & 58 & 22 & 16 & 17 & 16 & 15 & 66 & 47 & 56 & 26 \\
\hline & 3 & 77 & 65 & 59 & 42 & 18 & 21 & 17 & 16 & 58 & 46 & 33 & 25 \\
\hline & 4 & 95 & 82 & 61 & 46 & 17 & 18 & 18 & 18 & 67 & 50 & 37 & 28 \\
\hline \multirow[t]{4}{*}{5} & 1 & 83 & 72 & 54 & 40 & 17 & 15 & 16 & 16 & 61 & 44 & 35 & 26 \\
\hline & 2 & 82 & 64 & 49 & 34 & 16 & 13 & 15 & 11 & - & 41 & 32 & 22 \\
\hline & 3 & 64 & 56 & 44 & 33 & 13 & 14 & 14 & 14 & 52 & 38 & 26 & 19 \\
\hline & 4 & 80 & 63 & 46 & 30 & 13 & 13 & 13 & 16 & 54 & 35 & 29 & 19 \\
\hline \multirow[t]{4}{*}{6} & 1 & 12 & 13 & 11 & 10 & 14 & 13 & 10 & 10 & 54 & 34 & 29 & 18 \\
\hline & 2 & 86 & 71 & 54 & 38 & 16 & 15 & 16 & 15 & 63 & 44 & 31 & 26 \\
\hline & 3 & 81 & 69 & 54 & 41 & 14 & 15 & 12 & 14 & 59 & 41 & 27 & 19 \\
\hline & 4 & - & - & - & - & - & - & - & - & - & - & - & - \\
\hline \multirow{3}{*}{7} & 2 & 88 & 71 & 53 & 35 & 11 & 10 & 10 & 11 & 61 & 40 & 25 & 17 \\
\hline & 3 & 87 & 71 & 50 & 33 & 11 & 10 & 10 & 11 & 56 & 37 & 23 & 16 \\
\hline & 4 & 82 & 69 & 51 & 33 & 10 & 10 & 10 & 11 & 58 & 38 & 24 & 18 \\
\hline \multirow[t]{4}{*}{8} & 1 & - & - & - & - & - & - & - & - & - & - & - & - \\
\hline & 2 & - & - & - & - & - & - & - & - & - & - & - & - \\
\hline & 3 & - & - & - & - & - & - & - & - & - & - & - & - \\
\hline & 4 & - & - & - & - & - & - & - & - & - & - & - & - \\
\hline
\end{tabular}

${ }^{*}$ The results are expressed as a binding percentage. 


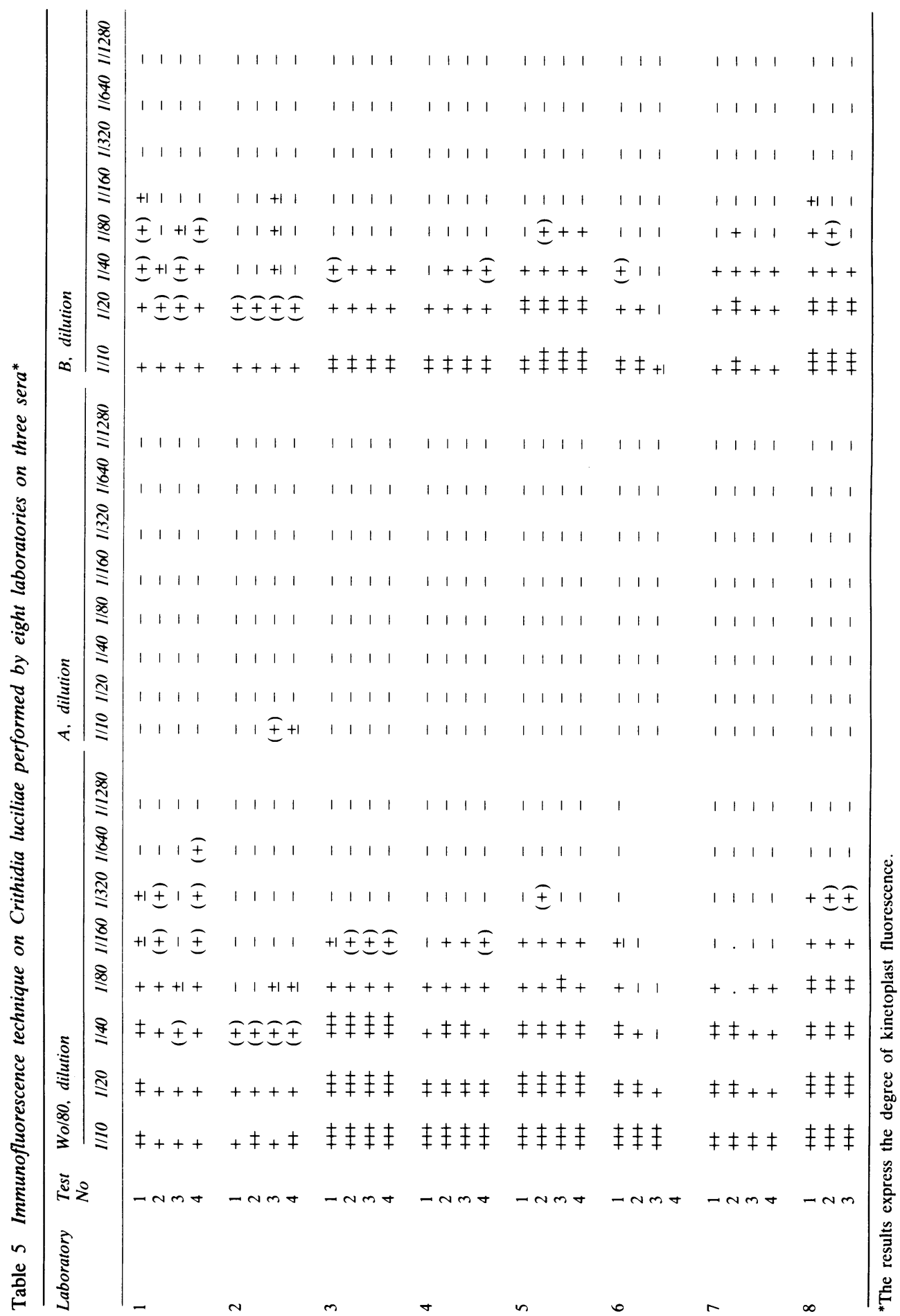


FAR R A S SA Y

The dilution curves from each of the assays were plotted and examined visually for linearity and parallelism. As no replication was carried out in the individual assays the linearity and parallelism of the dilution curves could not be tested statistically. Within assays coefficients of variation were therefore not determined. It was clear from the graphs that preparation $\mathrm{A}$ had no detectable activity in this assay method, and the results for this material were not considered further. For preparation B several data points fell outside the linear part of the dilution curve, and these points also were excluded. In a small proportion of assays no valid comparison seemed possible, and these assays were therefore discarded. The remaining data were included in a parallel line assay analysis according to Finney, ${ }^{15}$ in which straight parallel lines were fitted for each assay, and, from these, potency ratios of the preparations versus $\mathrm{Wo} / 80$ were calculated.

Fig. 1 shows the distribution of the potency ratios of $B$ versus $\mathrm{Wo} / 80$ from the individual assays; these ranged from 0.241 to 0.458 . (A potency ratio $R$ means that preparation $B$ was estimated to be $R$ times as potent as Wo/80.) Table 6 summarises these results and shows the geometric means and coefficients of variation within each laboratory. The laboratory means ranged from 0.260 to 0.365 . One way analysis of variance among these means showed that the variation between laboratories was statistically significant $\left(\mathrm{F}_{6 \cdot 19}=4.30, \mathrm{p}<0.01\right)$ when compared with the variation within laboratories. The overall geometric mean potency ratio was 0.313 with a $95 \%$ confidence interval of $0.282-0 \cdot 348$.

\section{IMMUNOFLUORESCENCE TECHNIQUE}

The results were calculated as the ratios of the titres of $\mathrm{B}$ versus $\mathrm{Wo} / 80$ at which the first position response (+) was recorded. Fig. 1 (lower panel)

Table 6 Geometric mean (GM) potency ratios of $B$ versus Wo/80 and geometric coefficients of variation $(G C V)^{16}$ in the individual laboratories

\begin{tabular}{|c|c|c|c|c|}
\hline \multirow[t]{2}{*}{ Laboratory } & \multicolumn{2}{|c|}{ Farr assay } & \multicolumn{2}{|c|}{ Crithidia luciliae } \\
\hline & $G M$ & $G C V(\%)$ & $G M$ & $G C V(\%)$ \\
\hline 1 & $0 \cdot 37$ & 18 & $0 \cdot 30$ & 94 \\
\hline 2 & $0 \cdot 29$ & 7 & $0 \cdot 50$ & 0 \\
\hline 3 & $0 \cdot 26$ & 13 & 0.39 & 39 \\
\hline 4 & $0 \cdot 31$ & 3 & $0 \cdot 25$ & 0 \\
\hline 5 & $0 \cdot 35$ & 9 & $0 \cdot 35$ & 49 \\
\hline 6 & $0 \cdot 31$ & 12 & 0.40 & 49 \\
\hline 7 & 0.32 & 9 & 0.50 & 0 \\
\hline 8 & - & - & $0 \cdot 25$ & 0 \\
\hline
\end{tabular}

$-=$ not done. shows the distribution of potency ratios of $B$ versus Wo/80, which ranged from $0 \cdot 125$ to $0 \cdot 5$. Most of the potency ratios were either 0.25 or 0.5 , the bimodality of the distribution reflecting the fact that the potencies were calculated as the ratios of titres. Table 6 summarises the results, showing the geometric means and coefficients of variation within each laboratory. The laboratory means ranged from 0.25 to 0.5 . One way analysis of variance among these means showed that, as with the Farr assay, the interlaboratory variation was statistically significant $\left(\mathrm{F}_{7.23}=2.83, \mathrm{p}<0.05\right)$. The overall geometric mean potency ratio was 0.355 with a $95 \%$ confidence interval of $0 \cdot 282-0.447$.

For preparation B it appeared that the potency ratios by the two methods of assay were broadly similar. In Fig. 1 it can be seen that all the potency

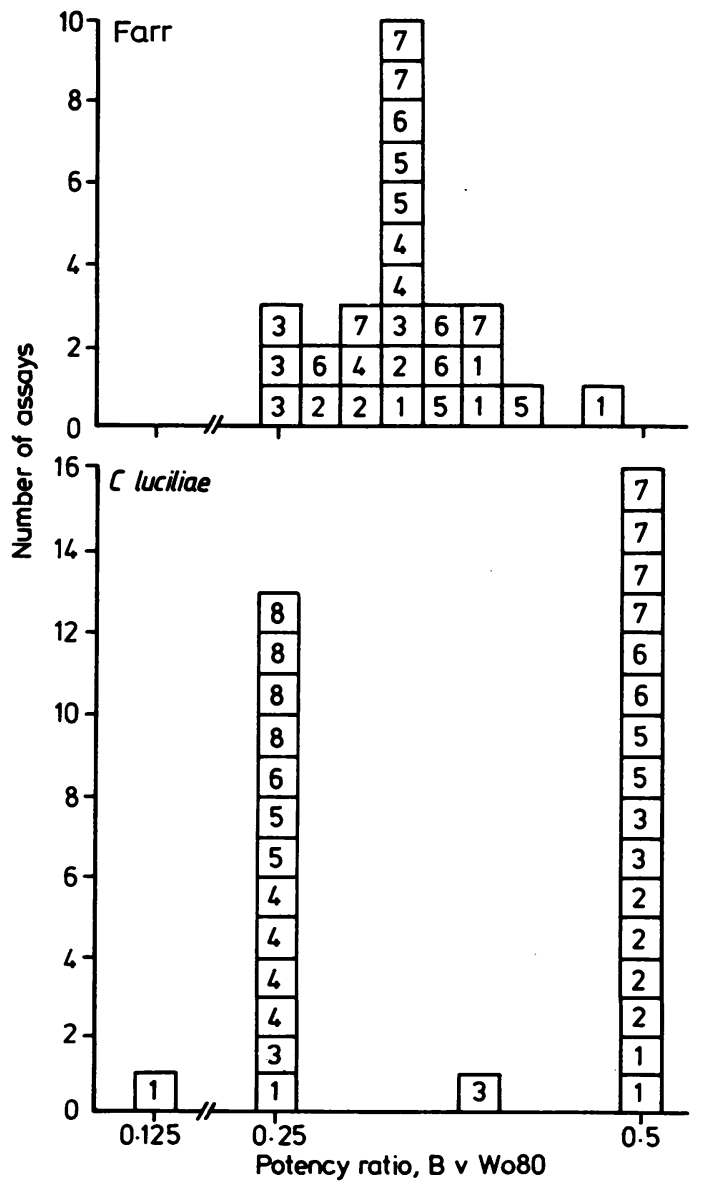

Fig. 1 Distribution of potency ratios of serum $B$ versus Wo/80, resulting from tests performed in eight laboratories (numbered 1-8) on four distinct days. 
ratios for the Farr assay lay between the two values $(0.25$ and 0.5$)$ which were most commonly obtained in the $C$ luciliae assay. The overall geometric mean potency ratios by the two methods were not significantly different, with the confidence interval for the mean potency ratio by the Farr assay being contained entirely within the confidence interval for the mean potency ratio by $C$ luciliae assay.

The following conclusions were reached: $(a)$ By the Farr assay the preparations $\mathrm{Wo}_{\mathrm{O}} / 80$ and $\mathrm{B}$ gave parallel dilution curves as judged from graphical plots of percentage binding against log concentration; (b) Potency ratios of $\mathrm{B} v \mathrm{Wo} / 80$ were significantly different among the individual laboratories for both assay methods, but the overall distributions were satisfactorily narrow. The geometric mean potency ratios by the two assay methods were not significantly different: $(c)$ Preparation A was inactive by both methods in all laboratories.

\section{Discussion}

The purpose of the subcommittee on standardisation of anti-dsDNA was to make available a serum with antibodies to dsDNA which could serve as an international standard, enabling the expression of results of quantitative anti-dsDNA assays in international units. The WHO expert committee on biological standardisation agreed that the serum Wo/80 met these criteria and declared that each vial of $0.5 \mathrm{ml}$ contains 100 international units of antidsDNA. The standard was designated: First international standard for anti-dsDNA.

In a recent study performed by 10 laboratories from all over the world, initiated by the Arthritis Foundation and Centers for Disease Control in Atlanta, it was shown that national standards could be calibrated in IU using $\mathrm{Wo} / 80$ as a reference preparation. All 10 laboratories considered $\mathrm{Wo} / 80$ to contain anti-dsDNA antibodies using various methods including enzyme linked immunosorbent assay (ELISA), the Farr assay, polyethylene glycol precipitation, Millipore filtration, complement fixation, and immunofluorescence techniques.

The vials are held and distributed by the International Laboratory for Biological Standards, located in the Central Laboratory of the Netherlands Red Cross Blood Transfusion Service, PO Box 9190, 1006 AD Amsterdam, The Netherlands. It is recommended that this standard is employed as a reference preparation for establishing national, regional, or local standards.

The patient was under care of Dr L Bouman of the Department of
International Medicine of the Free University of Amsterdam. an under regular observation by Dr A J G Swaak, who performed study on the clinical significance of anti-DNA. Freeze drying and distribution of the vials was carried out by $\mathrm{Mr} \mathrm{G} \mathrm{H}$ Spiller of Amersham International plc. Tests for autoantibodies were pe formed under the supervision of $\mathrm{Dr} \mathrm{H} \mathrm{G} \mathrm{M} \mathrm{Geertzen} \mathrm{of} \mathrm{the}$ Department of Autoimmune Diseases of the Central Laboratory \& the Blood Transfusion Service of Amsterdam. In the san? department Dr R Smeenk performed the degradation tests. The following members of the subcommittee on standardisation $\overrightarrow{\text { of }}$ anti-dsDNA participated in the collaborative study: L A Aarden G J Fournié. K Helmke, E J Holborow, G D Johnson. J Jonssoon R N Maini. A D Steinberg. E M Tan. Other members of the subcommittee were Dr Alarçon-Segovia. R M Bennett, R I Car? A Fagraeus, I Hanna, J Holian, G R V Hughes, D Koffler. P 底 Lambert, R W Lightfoot, P H Schur, D Stollar, N Talidy Amersham kits were kindly provided by Amersham Internation plc, and Crithidia luciliae preparations by the Central Laborato of the Netherlands Red Cross Blood Transfusion Service.

\section{References}

I Seligmann M. Serologic dans le serum des malades atteints lupus erythematosus disseminé. CR Acad $S_{c i}$ (Paris) 1957: 24을 $2+3-55$

2 Ceppelini R. Polli E. Celada F. A DNA-reacting factor $\overrightarrow{\mathrm{m}}$ serum of a patient with lupus erythematosus diffusus. Proc $S \&$ Exp Biol Med 1957; 96: 572-4.

3 Miesscher P. Strassle R. New serologic methods for tiT detection of the L.E. factor. Vox Sang 1957: 2: 283-95.

+ Robbins W C. Holman H R. Deicher H R. Kunkel H C্ Complement fixation with cell nuclei and DNA in lypus erythematosus. Proc Soc Exp Biol Med 1957; 96: 575-9. О 0

5 Feltkamp T E W, ed. The significance of the determinatie anti-DNA and DNA/anti-DNA complexes. Scand J Rheungitiol 1975: suppl 11

6 Maini R N. Holborow E J. eds. Detection and measurement anti-DNA antibodies. Ann Rheum Dis 1977: 36 (suppl 1).

7 Aarden L A. Smeenk R J T. Measurement of antibodic specific for DNA. In: Lefkovits I. Pernis B. eds. Immunologic methods. Vol 2. New York: Academic Press. 1981: 75.

8 Smeenk R. A comparison of four different anti-DNA assay In: Pal S B, ed. Immunoassay technology. Vol 2. Berlin: Waltg de Gruyter. 1986: 145-66.

9 Aarden L A. Lakmaker F. De Groot E R. Immunology DNA. IV. Quantitative aspects of the Farr assay. J Immungl Methods 1976: 11: 153-63

10 Aarden L A. Last minute subjects. Scand J Rheumatol 1978 (suppl 11): 65 .

11 Kirkwood T B L. Predicting the stability of biological standar and products. Biometrics 1977; 33: 736-12.

12 Kirkwood T B L. Tydeman M S. Design and analysis $\Theta$ accelerated degradation tests for the stability of biologic standards. II. A flexible computer program for data analysis. Biol Stand 1984: 12: 207.

13 Tydeman M S. Kirkwood T B L. Design and analysis accelerated degradation tests for the stability of biologic standards. I. Propertics of maximum likelihood estimators. Nb Biol Stand 1984: 12: 195-206.

14 Holian J. Griffiths I D. Glass D N, Maini R N, Scott J N Human anti-DNA antibody: reference standards for diagnoss and management of systemic lupus erythematosus. Ann Rheukn Dis 1975: 34: 438-43.

15 Finney D J. Statistical method in biological assay. New Yordo Academic Press. 1978.

16 Ǩirkwood T B L. Geometric means and measures of dispersio Biometrics 1979; 35: 908 . 